\title{
The Steroid Metabolome in Men With Mood and Anxiety Disorders
}

\author{
M. DUŠKOVÁ ${ }^{1}$, M. HILL ${ }^{1}$, M. BIČÍKOVÁ ${ }^{1}$, M. ŠRÁMKOVÁ ${ }^{1}$, D. ŘÍPOVÁ ${ }^{2}$, P. MOHR $^{2}$, \\ L. STÁRKA ${ }^{1}$ \\ ${ }^{1}$ Institute of Endocrinology, Prague, Czech Republic, ${ }^{2}$ National Institute of Mental Health, Klecany, \\ Czech Republic
}

Received May 5, 2015

Accepted May 20, 2015

\begin{abstract}
Summary
The mood and behavior of individuals result from an orchestra of many factors. Among them steroids play an important role; however, only several common hormones have been investigated in this respect. It has been demonstrated that some steroid metabolites long considered merely the products of steroid hormone metabolism in fact possess considerable activity in the CNS. For this reason we studied the steroid metabolome including 50 analytes in 20 men with depression, 20 men with anxiety and 30 healthy controls. Significant differences were found not only between controls and men with either depression or anxiety, but also between men with depression and anxiety. Particularly striking were those steroids until now not generally associated with depression or anxiety, namely conjugated steroid forms, especially sulfates.
\end{abstract}

\section{Key words}

Steroid hormones • Allopregnanolone • Dehydroepiandrosterone

- Affective depression • Anxiosity • Steroid sulfates • Steroid conjugates

\section{Corresponding author}

M. Dušková, Institute of Endocrinology, Národní 8, 11694 Prague 1, Czech Republic. E-mail: mduskova@endo.cz

\section{Introduction}

In affective disorders, it is generally accepted that a crucial role for neurotransmission is played by the serotoninergic (Steiner 2011) and noradrenergic systems with concomitant activation of the axis hypothalamus pituitary - adrenals (HPA) (Horstmann and Binder 2011, Detka et al. 2013, Herbert 2013, Belvederi et al. 2014, Crowly and Gridler 2014, Jacobson 2014) However, many other hormones and various factors have been identified as modulators of mood and behavior in such disorders. Recent studies have described the role of brainderived neurotrophic factor (BDNF) (Pluchino et al. 2013, Numakawa et al. 2014), thyroid hormones (Duntas and Mails 2013), inflammation (Halaris 2013), immunity (Pitychoutis and Papadopoulou-Daifoti 2010), melatonin (Boyce and Hopwood 2013), oxytocin and vasopressin (Scantamburlo et al. 2009, Matsuzaki et al. 2012), the renin-angiotensin-aldosterone system (Franklin et al. 2012, Murck et al. 2012), the cannabinoid system (Martykánová 2010, Gorzalka and Hill 2011, Smaga et al. 2014), ghrelin (Steiger et al. 2011) and nutritional factors. Many other associations of various factors with depression are given in the paper by Lang and Borgwardt (2013).

Despite this variety of data, only some hormones and factors have successfully been used for biochemical characterisations of affective disorders. Among the most repeatedly validated biomarkers of depression are a decrease in platelets and lymphocytes binding the serotonin transporter, hypercortisolemia, hypocholesteremia, a decrease in brain-derived neurotrophic factor, a decrease in CREB phosphorylation, and an increase in interleukin 6 (Caruncho and RiveraBaltanás 2010).

Neuroactive steroids occupy a particular position, acting on $\mathrm{GABA}_{\mathrm{A}}$ receptors $\left(\mathrm{GABA}_{\mathrm{A}} \mathrm{Rs}\right)$ to potentiate the effects of GABA on these receptors. There is considerable evidence for the plasticity of $\mathrm{GABA}_{\mathrm{A}} \mathrm{Rs}$ associated with altered levels of neurosteroids. These effects have been observed for ovarian steroids (EstradaCamarena et al. 2010, Soares 2013, MacKenzie and Maguire 2014, Schiller et al. 2014, Pařízek et al. 2014), 
testosterone (Amore et al. 2012, Khera 2013, McHenry et al. 2014), dehydroepiandrosterone (DHEA) (Veronese et al. 2015) and other neurosteroids (Reddy 2010, PatteMensah et al. 2014).

For this reason we analyzed the steroid metabolome in order to discover differences that could potentially lead to affective depression or anxiety.

\section{Materials and Methods}

\section{Subjects}

For this study we used three groups of subjects: 1) twenty patients with depressive disorder (unipolar or bipolar) according to the International Classification of Diseases, $10^{\text {th }}$ Revision (ICD-10) (WHO, 2004), 2) twenty patients with specific anxiety disorder (Phobia, Panic Disorder, Obsessive-compulsive Disorder, Generalized Anxiety Disorder, Mixed Anxiety Depressive Disorder, Acute Reaction to Stress, Adjustment Disorder, Post-traumatic Stress Disorder) according to the ICD-10, and 3) thirty healthy matching controls. The subjects were 18-45 years old (men with depression: mean age $33.8 \pm 8.09$, median 35 years of age; men with anxiety: mean age $30.25 \pm 7.63$, median 27.5 ; controls: mean age $28.56 \pm 7.64$, median 26.5). Their BMI was at the border of normal and over-weight, with a BMI of 24.1 for men with depression $(22.6,26.6)$ (median and $95 \%$ continence interval), $25.2(22.8,28.9)$ for men with anxiety and $24.6(23,27.1)$ for controls.

The diagnosis of psychiatric disorder was confirmed using The Mini-International Neuropsychiatric Interview (M.I.N.I.) (Sheehan et al. 1998). The interview was performed by an independent clinical psychiatrist. Patients were required to have a minimum symptom severity (depressive or anxiety) of 4 on the Clinical Global Impressions Scale (CGI) (Guy 1976), suggesting at least moderately severe illness.

Exclusion criteria were: another psychiatric diagnosis on Axis I (especially organic disorder of the CNS, abuse and/or dependence on psychoactive substances), incapacity to sign an informed consent form, severe metabolic or endocrine illness, treated or untreated, and administration of drugs known to change steroid levels. In addition, healthy controls had to be free of any psychiatric disorder (both current and past), including organic impairment of the CNS, abuse and/or dependence on psychoactive substances. All controls were non-smokers. The Ethical Committee of the Institute of Endocrinology in Prague approved the protocol of the study, and written informed consent was obtained from all participants.

\section{Blood sampling}

Blood samples were drawn at 7 a.m. following overnight fasting from the cubital or forearm vein. Each sample was collected into a cooled plastic tube containing $100 \mu \mathrm{l}$ of $5 \%$ EDTA. Plasma was obtained by centrifugation for $5 \mathrm{~min}$ at $2000 \mathrm{~g}$ at $4{ }^{\circ} \mathrm{C}$, separated and frozen within half an hour of being drawn from the subject, and stored at $-80{ }^{\circ} \mathrm{C}$ until analyzed.

\section{Analytical methods \\ Analyses measured by RIA and IRMA}

17-hydroxy-pregnenolone was measured by the RIA method, and 17-hydroxy-pregnenolone sulfate by the same method after hydrolysis (Hill et al. 1999). Estradiol was measured using an RIA kit from Orion (Finland) and 17-hydroxy-progesterone using a kit from Immunotech (France). Cortisol was measured using an RIA kit from Orion (Finland). Sex hormones bounding globulin (SHBG) were measured by the IRMA method (Orion, Finland). Kits from Immunotech (France) were used to measure LH and FSH (IRMA kit).

\section{Steroids measured by GC/MS method}

The levels of unconjugated steroids and steroid polar conjugates after hydrolysis were concomitantly measured in cubital vein blood using the GC-MS method (Hill et al. 2010).

In brief, free steroids were extracted from plasma by diethyl-ether; steroid conjugates were hydrolyzed and extracted. The resulting residues were derivatized by methoxyamine hydrochloride and analyzed by GC/MS as follows.

Steroids were purchased from Steraloids (Newport, RI, USA), Sylon B from Supelco (Bellefonte, PA, USA), methoxylamine hydrochloride from Sigma (St. Louis, MO, USA) and solvents from Merck (Darmstadt, Germany).

Instruments: Measurements of steroid levels were done on a GCMS-QP2010 Plus system by Shimadzu (Kyoto, Japan) consisting of a gas chromatograph equipped with automatic flow control, an AOC-20s autosampler, and a single quadrupole detector with an adjustable electron voltage of $10-195 \mathrm{~V}$. A capillary column with a medium polarity RESTEK Rxi column (diameter $0.25 \mathrm{~mm}$, length $15 \mathrm{~m}$, film thickness $0.1 \mu \mathrm{m}$ ) was used for analyses. Electronimpact ionization 
with electron voltage fixed at $70 \mathrm{~V}$ and emission current set to $160 \mu \mathrm{A}$ was used. The temperatures of the injection port, ion source and interface were maintained at $220{ }^{\circ} \mathrm{C}$, $300{ }^{\circ} \mathrm{C}$, and $310^{\circ} \mathrm{C}$, respectively. Analyses were carried out in the splitless mode with a constant linear velocity of the carrier gas $(\mathrm{He})$, which was maintained at $60 \mathrm{~cm} / \mathrm{s}$. The septum purge flow was set at $3 \mathrm{ml} / \mathrm{min}$. The samples were injected using the high pressure mode $(200 \mathrm{kPa})$, which was maintained for $1 \mathrm{~min}$. The detector voltage was set to $1.4 \mathrm{kV}$.

\section{Statistical data analysis}

The changes of steroid levels were evaluated using a repeated measures ANOVA model consisting of a group factor, explaining differences between groups, and an age factor. Due to the non-Gaussian data distribution and non-constant variance, the original data was transformed by a power transformation to attain symmetric distribution of the data and residuals as well as homoscedasticity (Meloun et al. 2000). The homogeneity of the transformed data was checked by residual analysis as described elsewhere (Meloun et al. 2002).

\section{Results}

The results of analyses and statistical factors for age and group are given in Table 1.

Both depressive and anxious men differed significantly $(\mathrm{p}<0.05)$ from controls in a considerable number of hormonal parameters. Higher levels in controls compared to all patients were found for the free steroids progesterone, estrone, dihydrotestosterone, allopregnanolone, sulfates of pregnenolone, $20 \alpha$-dihydropregnenolone, estrone, allopregnanolone, isopregnanolone, androsterone and epiandrosterone, and conjugates of pregnanolone, both $5 \beta$-pregnanediols, etiocholanolone and $5 \alpha$-androstane $3 \beta, 17 \beta$-diol. Lower levels in controls were only found for $\mathrm{LH}$, androstenediol, pregnenolone and 16 $\alpha$-hydroxy-pregnenolone.

Men with anxiety disorders and depression mainly differed from controls $(p<0.05)$ in having lower levels of estradiol and higher levels of $7 \beta$-hydroxyDHEA and 5-androsten-3 $\beta, 7 \beta, 17 \beta$-triol. Men with depression additionally had higher levels of DHEA, 16 $\alpha$-hydroxy-DHEA, epiandrosterone, cortisol and conjugated $5 \beta$-androstene-3 $\alpha, 17 \beta$-diol and lower levels of 17-hydroxypregnenolone sulfate and dehydroepiandrosterone sulfate (DHEAS).

There were significant differences between men with depression and men with anxiety for $20 \alpha$-dihydropregnenolone sulfate, estradiol and cortisol, which were significantly higher in depressive patients, and for 17-hydroxypregnenolone sulfate, 5-androstene $3 \beta, 7 \beta, 17 \beta$-triol, progesterone and estrone sulfate, which were lower.

\section{Discussion}

Neurosteroids are positive allosteric modulators of $\mathrm{GABA}_{\mathrm{A}}$ receptors with powerful antiseizure, anxiolytic, analgesic and antidepressive activity in diverse animal models and in several clinical studies, and increase both synaptic and tonic inhibition. Sulfated neurosteroids such as pregnenolone sulfate, which are negative $\mathrm{GABA}_{\mathrm{A}}$ receptor modulators, act as memoryenhancing agents. Other ion channels such as AMPA, EAAT, NMDA- and metabotropic glutamate receptors (mGluR1 to mGluR8) have also recently received more attention in studies of depression (Hill et al. 2015).

Among the steroids analyzed in this study are compounds that have repeatedly been recognized as neuroactive steroids, e.g. allopregnanolone (Shule et al. 2014), testosterone (McHenry et al. 2014), pregnenolone (Reddy 2010), dehydroepiandrosterone (Kurita et al. 2013) and pregnanolone (Holubová et al. 2014). Differences in their levels between healthy controls and psychiatric patients with depression or anxiety were found for some but not all of them. For instance, practically no association with psychopathy was found for testosterone, though the literature frequently reports gender differences in the incidence of depression probably due to sexual hormones levels. Cortisol levels were found to be higher in men with depression than in controls, as reported in literature (Herbert 2013), but not in men with anxiety. Also, dehydroepiandrosterone and dehydroepiandrosterone sulfate levels differed from controls in patients with depression but not those with anxiety. The sulfated neurosteroids pregnenolone sulfate and DHEAS as well as DHEA have clear antidepressant effects in animals and humans (Kurita et al. 2013). Pregnenolone sulfate and DHEAS also enhance cognition in animals (Sabeti et al. 2007, Carta et al. 2012). DHEA, a precursor of DHEAS and a dietary supplement, has been widely investigated as a potential antidepressant (Peixoto et al. 2014). However, studies investigating DHEA and DHEAS concentrations in depression have yielded inconsistent results with both increases and decreases during major depression. Overall, there are 


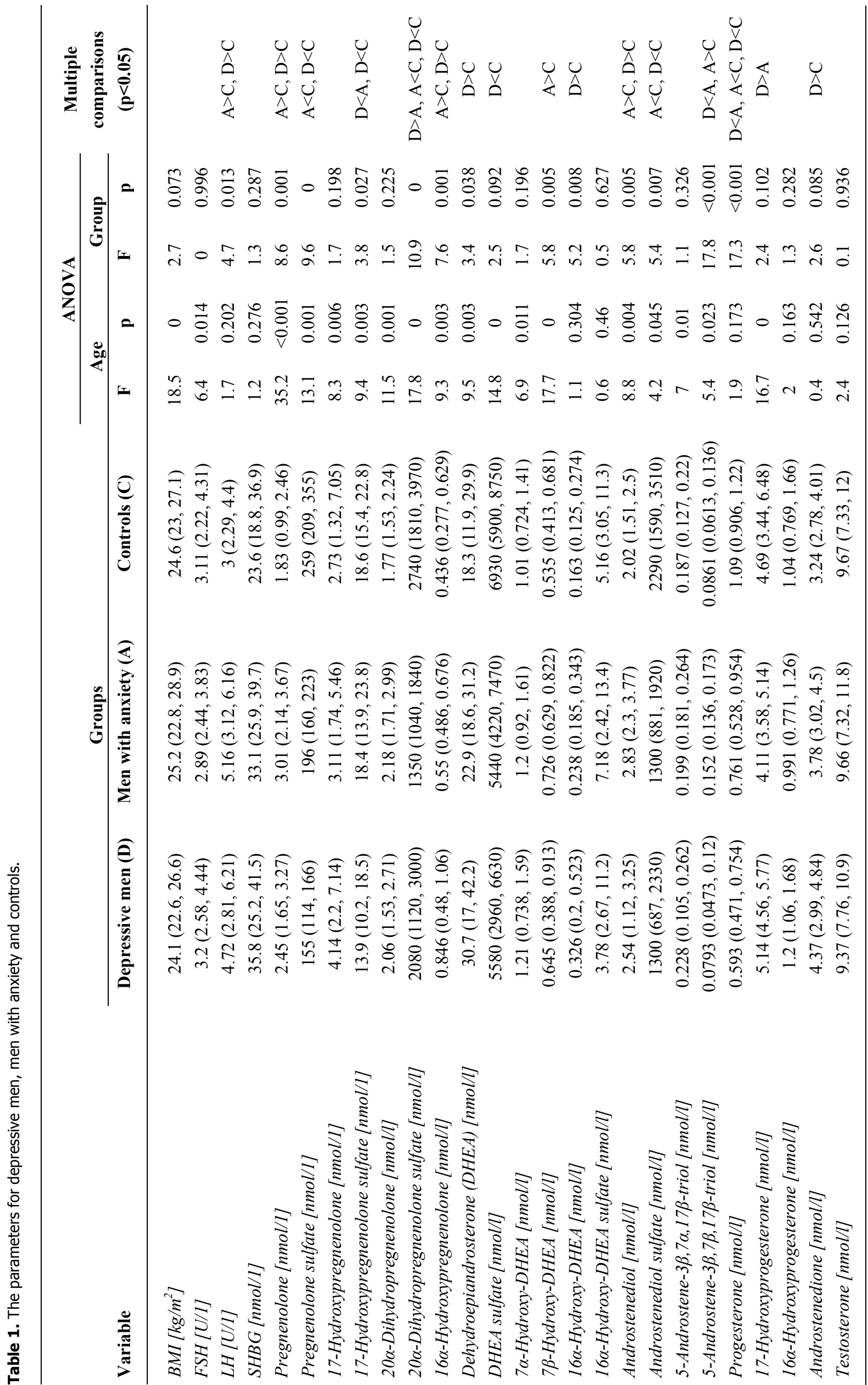




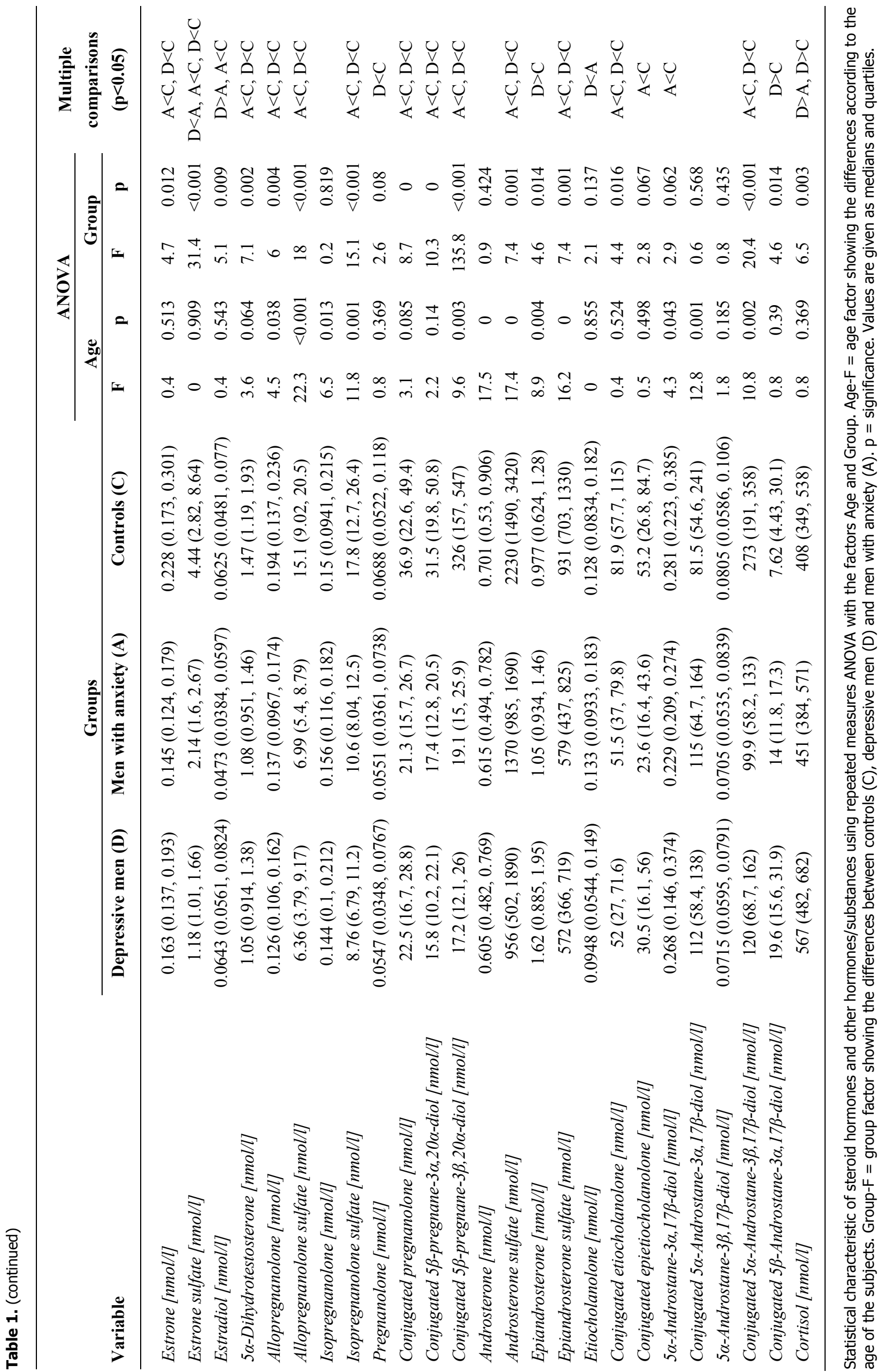


indications that adjunct DHEA could produce beneficial effects in patients with depression. Attention should be paid to the role of 7-hydroxylated derivatives of DHEA, found in this study to be characteristic for anxiety.

There is considerable evidence for the involvement of neurosteroids in the aetiology of anxiety disorders. Neurosteroids such as allopregnanolone and tetrahydrodeoxycortisone (THDOC) are potent anxiolytic agents (MacKenzie and Maguire 2013, Nuss 2015). Progesterone also has anxiolytic activity in animal models. Administration of progesterone produces similar sedative-anxiolytic effects in men and women (Bristot et al. 2014). In our hands men with depression and men with anxiety differed mainly in the levels of $20 \alpha$-dihydropregnenolone sulfate, estradiol and cortisol, and in 17-hydroxypregnenolone sulfate, 5-androstene $3 \beta, 7 \beta, 17 \beta$-triol, progesterone and estrone sulfate.

The results of our study include several striking findings. The anticonvulsive and anxiolytic steroid allopregnanolone was less associated with changes of mood than its sulfate, and sulfates and conjugates were generally more frequently markers of such changes than free steroids. The greatest difference between controls and psychiatric patients was found for conjugated
$5 \beta$-pregnane-3 $\beta, 20 \alpha$-diol.

Considering the role of steroid sulfates in the brain it is necessary to take into account that we measured circulating steroid levels in blood, which do not necessarily correspond to levels in the brain or even in its specific regions. Sulfates have a limited ability to cross the blood-brain barrier, and the activity of sulfotransferase in the brain, which is responsible for the sulfatation of steroids, is very low (Krríž et al. 2005). Generally, sulfates and conjugates of steroids in are higher in plasma than free steroids. Despite this, the ratio of free and conjugated or sulfatated steroids is an important feature of the steroid metabolome, and it could be reflected in various target regions in the brain. In addition, levels of selected steroids in the plasma or serum could be helpful as markers of psychiatric disorders.

\section{Conflict of Interest}

There is no conflict of interest.

\section{Acknowledgements}

The study was supported by grant IGA MZ ČR No. NT/13890-5.

\section{References}

AMORE M, INNAMORATI M, COSTI S, SHER L, GIRARDI P, POMPILI M: Partial androgen deficiency, depression, and testosterone supplementation in aging men. Int J Endocrinol 2012: 280724, 2012.

BELVEDERI MURRI M, PARIANTE C, MONDELLI V, MASOTTI M, ATTI AR, MELLACQUA Z, ANTONIOLI M, GHIO L, MENCHETTI M, ZANETIDOU S, INNAMORATI M, AMORE M: HPA axis and aging in depression: systematic review and meta-analysis. Psychoneuroendocrinology 41: 46-62, 2014.

BOYCE P, HOPWOOD M: Manipulating melatonin in managing mood. Acta Psychiatr Scand Suppl 444: 16-23, 2013.

BRISTOT G, ASCOLI B, GUBERT C, PANIZZUTTI B, KAPCZINSKI F, ROSA AR: Progesterone and its metabolites as therapeutic targets in psychiatric disorders. Expert Opin Ther Targets 18: 679-690, 2014.

CARTA MG, BHAT KM, PRETI A: GABAergic neuroactive steroids: a new frontier in bipolar disorders? Behav Brain Funct 8(61): 1-8, 2012.

CARUNCHO HJ, RIVERA-BALTANÁS T: Biomarkers of depression (in Spanish). Rev Neurol 50: 470-476, 2010.

CROWLEY SK, GIRDLER SS: Neurosteroid, GABAergic and hypothalamic pituitary adrenal (HPA) axis regulation: what is the current state of knowledge in humans? Psychopharmacology (Berl) 231: 3619-3634, 2014.

DETKA J, KUREK A, BASTA-KAIM A, KUBERA M, LASOŃ W, BUDZISZEWSKA B: Neuroendocrine link between stress, depression and diabetes. Pharmacol Rep 65: 1591-1600, 2013.

DUNTAS LH, MAILLIS A: Hypothyroidism and depression: salient aspects of pathogenesis and management. Minerva Endocrinol 38: 365-377, 2013.

ESTRADA-CAMARENA E, LÓPEZ-RUBALCAVA C, VEGA-RIVERA N, RÉCAMIER-CARBALLO S, FERNÁNDEZ-GUASTI A: Antidepressant effects of estrogens: a basic approximation. Behav Pharmacol 21: 451-464, 2010. 
FRANKLIN M, BERMUDEZ I, HLAVACOVA N, BABIC S, MURCK H, SCHMUCKERMAIR C, SINGEWALD N, GABURRO S, JEZOVA D: Aldosterone increases earlier than corticosterone in new animal models of depression: is this an early marker? J Psychiatr Res 46: 1394-1397, 2012.

GORZALKA BB, HILL MN: Putative role of endocannabinoid signaling in the etiology of depression and actions of antidepressants. Prog Neuropsychopharmacol Biol Psychiatry 35: 1575-1585, 2011.

GUY W: ECDEU assessment manual for psychopharmacology - revised. Rockville, MD, U.S. Department of Health and Human Services, 1976, pp 218-222.

HALARIS A: Inflammation, heart disease, and depression. Curr Psychiatry Rep 15: 400, 2013.

HERBERT J: Cortisol and depression: three questions for psychiatry. Psychol Med 43: 449-469, 2013.

HILL M, HAMPL R, LUKÁC D, LAPCÍK O, POUZAR V, SULCOVÁ J: Elimination of cross-reactivity by addition of an excess of cross-reactant for radioimmunoassay of 17alpha-hydroxy-pregnenolone. Steroids 64: 341-355, 1999.

HILL M, PARIZEK A, CIBULA D, KANCHEVA R, JIRASEK JE, JIRKOVSKA M, VELIKOVA M, KUBATOVA J, KLIMKOVA M, PASKOVA A, ZIZKA Z, KANCHEVA L, KAZIHNITKOVA H, ZAMRAZILOVA L, STARKA L: Steroid metabolome in fetal and maternal body fluids in human late pregnancy. $J$ Steroid Biochem Mol Biol 122: 114-132, 2010.

HILL M, DUŠKOVÁ M, STÁRKA L: Dehydroepiandrosterone, its metabolites and ion channels. $J$ Steroid Biochem Mol Biol 145: 293-314, 2015.

HOLUBOVA K, NEKOVAROVA T, PISTOVCAKOVA J, SULCOVA A, STUCHLIK A, VALES K: Pregnanolone glutamate, a novel use-dependent NMDA receptor inhibitor, exerts antidepressant-like properties in animal models. Front Behav Neurosci 16: 130, 2014.

HORSTMANN S, BINDER EB: Glucocorticoids as predictors of treatment response in depression. Harv Rev Psychiatry 19: 125-143, 2011.

JACOBSON L: Hypothalamic-pituitary-adrenocortical axis: neuropsychiatric aspects. Compr Physiol 4: 715-738, 2014.

KHERA M: Patients with testosterone deficit syndrome and depression. Arch Esp Urol 66: 729-736, 2013.

KŘÍŽ L, BIČÍKOVÁ M, HILL M, HAMPL R: Steroid sulfatase and sulfuryl transferase activity in monkey brain tissue. Steroids 70: 960-969, 2005.

KURITA H, MAESHIMA H, KIDA S, MATSUZAKA H, SHIMANO T, NAKANO Y, BABA H, SUZUKI T, ARAI H: Serum dehydroepiandrosterone (DHEA) and DHEA-sulfate (S) levels in medicated patients with major depressive disorder compared with controls. J Affect Disord 146: 205-212, 2013.

LANG UE, BORGWARDT S: Molecular mechanisms of depression: perspectives on new treatment strategies. Cell Physiol Biochem 31: 761-777, 2013.

MACKENZIE G, MAGUIRE J: Neurosteroids and GABAergic signaling in health and disease. Biomol Concepts 4: 29-42, 2013.

MACKENZIE G, MAGUIRE J: The role of ovarian hormone-derived neurosteroids on the regulation of GABAA receptors in affective disorders. Psychopharmacology (Berl) 231: 3333-3342, 2014.

MARTYKÁNOVÁ L: Endocannabinoid system II--the role in addictive behaviour, depression and in pathology of eating behavior (in Czech). Cas Lek Cesk 149: 368-371, 2010.

MATSUZAKI M, MATSUSHITA H, TOMIZAWA K, MATSUI H: Oxytocin: a therapeutic target for mental disorders. J Physiol Sci 62: 441-444, 2012.

MCHENRY J, CARRIER N, HULL E, KABBAJ M: Sex differences in anxiety and depression: role of testosterone. Front Neuroendocrinol 35: 42-57, 2014.

MELOUN M, HILL M, MILITKÝ J, KUPKA K: Transformation in the PC-aided biochemical data analysis. Clin Chem Lab Med 38: 553-559, 2000.

MELOUN M, MILITKÝ J, HILL M, BRERETON RG: Crucial problems in regression modelling and their solutions. Analyst 127: 433-450, 2002.

MURCK H, SCHÜSSLER P, STEIGER A: Renin-angiotensin-aldosterone system: the forgotten stress hormone system: relationship to depression and sleep. Pharmacopsychiatry 45: 83-95, 2012. 
NUMAKAWA T, RICHARDS M, NAKAJIMA S, ADACHI N, FURUTA M, ODAKA H, KUNUGI H: The role of brain-derived neurotrophic factor in comorbid depression: possible linkage with steroid hormones, cytokines, and nutrition. Front Psychiatry 26: 136, 2014.

NUSS P: Anxiety disorders and GABA neurotransmission: a disturbance of modulation. Neuropsychiatr Dis Treat 11: 165-175, 2015.

PAŘİZEK A, MIKEŠOVÁ M, JIRÁK R, HILL M, KOUCKÝ M, PAŠKOVÁ A, VELÍKOVÁ M, ADAMCOVÁ K, ŠRÁMKOVÁ M, JANDÍKOVÁ H, DUŠKOVÁ M, STÁRKA L: Steroid hormones in the development of postpartum depression. Physiol Res 63 (Suppl 2): S277-S282, 2014.

PATTE-MENSAH C, MEYER L, TALEB O, MENSAH-NYAGAN AG: Potential role of allopregnanolone for a safe and effective therapy of neuropathic pain. Prog Neurobiol 113: 70-78, 2014.

PEIXOTO C, DEVICARI CHEDA JN, NARDI AE, VERAS AB, CARDOSO A: The effects of dehydroepiandrosterone (DHEA) in the treatment of depression and depressive symptoms in other psychiatric and medical illnesses: a systematic review. Curr Drug Targets 15: 901-914, 2014.

PITYCHOUTIS PM, PAPADOPOULOU-DAIFOTI Z: Of depression and immunity: does sex matter? Int $J$ Neuropsychopharmacol 13: 675-689, 2010.

PLUCHINO N, RUSSO M, SANTORO AN, LITTA P, CELA V, GENAZZANI AR: Steroid hormones and BDNF. Neuroscience 239: 271-279, 2013.

REDDY DP: Neurosteroids: Endogenous role in the human brian and therapeutic potentials. Prog Brain Res 186: 113-137, 2010.

SABETI J, NELSON TE, PURDY RH, GRUOL DL: Steroid pregnenolone sulfate enhances NMDA-receptorindependent long-term potentiation at hippocampal CA1 synapses: role for L-type calcium channels and sigma-receptors. Hippocampus 17: 349-369, 2007.

SCANTAMBURLO G, ANSSEAU M, GEENEN V, LEGROS JJ: Oxytocin: From milk ejection to maladaptation in stress response and psychiatric disorders. A psychoneuroendocrine perspective. Ann Endocrinol (Paris) 70: 449-454, 2009.

SCHILLER CE, MELTZER-BRODY S, RUBINOW DR: The role of reproductive hormones in postpartum depression. CNS Spectr 29: 1-12, 2014.

SCHÜLE C, NOTHDURFTER C, RUPPRECHT R: The role of allopregnanolone in depression and anxiety. Prog Neurobiol 113: 79-87, 2014.

SHEEHAN DV, LECRUBIER Y, HARNETT-SHEEHAN K, AMORIM P, JANAVS J, WEILLER E, HERGUETA T, BAKER R, DUNBAR G: The Mini International Neuropsychiatric Interview (M.I.N.I.): the development and validation of a structured diagnostic psychiatric interview for DSM-IV and ICD-10. J Clin Psychiatry 59 (Suppl 20): 22-33, 1998.

SMAGA I, BYSTROWSKA B, GAWLIŃSKI D, PRZEGALIŃSKI E, FILIP M: The endocannabinoid/endovanilloid system and depression. Curr Neuropharmacol 12: 462-474, 2014.

SOARES CN: Depression in peri- and postmenopausal women: prevalence, pathophysiology and pharmacological management. Drugs Aging 30: 677-685, 2013.

STEIGER A, DRESLER M, SCHÜSSLER P, KLUGE M: Ghrelin in mental health, sleep, memory. Mol Cell Endocrinol 340: 88-96, 2011.

STEINER M: Serotonin, depression, and cardiovascular disease: sex-specific issues. Acta Physiol (Oxf) 203: 253-258, 2011.

VERONESE N, DE RUI M, BOLZETTA F, ZAMBON S, CORTI MC, BAGGIO G, TOFFANELLO ED, CREPALDI G, PERISSINOTTO E, MANZATO E, SERGI G: Serum dehydroepiandrosterone sulfate and incident depression in the elderly: The Pro.V.A. Study. Am J Geriatr Psychiatry 23: 863-871, 2015.

WORLD HEALTH ORGANIZATION: International Statistical Classification of Diseases and Health Related Problems. 10th Revision, Geneva 2004. 